\title{
I.В. ХОМ'ЯК
}

Житомирський державний університет імені Івана Франка вул. Велика Бердичівська, 51, м. Житомир, 10008, Україна ecosystem_lab@ukr.net

\section{НОВЕ МICЦЕЗНАХОДЖЕННЯ ВOTRYCHIUM LUNARIA (OPHIOGLOSSACEAE) HА TEPИTOPIÏ ЦЕНТРАЛЬНОГО ПОЛІССЯ}

К лю ч екологічний спектр

Нові дані, отримані науковцями з проблем популяційної екології, вимагають, зокрема щодо знаходження нових рідкісних і реліктових видів, перегляду традиційних уявлень про них і підходів до їхньої охорони. Так, думка про надмірну чутливість багатьох із цих видів до антропогенних факторів усе частіше піддається сумніву (Дідух, 2008). Водночас запровадження жорсткого заповідного режиму нерідко призводить до скорочення чисельності їхніх популяцій.

Під час ревізії нешодавно виявленого місцезнаходження Cypripedium calceolus L. на території Словечансько-Овруцького кряжа (Центральне Полісся) ми натрапили на численну популяцію Botrychium lunaria (L.) Sw. Ця знахідка має важливе значення з кількох причин. По-перше, це - новий локалітет, невідомий раніше. По-друге, на відміну від інших місцезнаходжень виду на території України, популяція нараховує більше 20 особин, а це вже досить багато. По-третє, вона перебуває під впливом помірного антропогенного тиску.

Botrychium lunaria (Ophioglossaceae s.l. = Botrychiaceae s.sfr.) - голарктичний вид iз диз'юнктивним ареалом. В Україні трапляється у лісовій, рідше - в лісостеповій зонах, в Українських Карпатах і Кримських горах. Для території Житомирської обл. наводиться місцезнаходження в Богунському лісництві Житомирського р-ну Житомирської обл. (Орлов, Костриця, Таргонський, 1997; Орлов, 2005). За словами О.О. Орлова, в цьому локалітеті виявлено лише один екземпляр $B$. lunaria. За літературними даними, в околицях Житомира цей вид знаходили Р. Собкевич і К. Гольде (24.05.1872) в Андрушівському р-ні (поблизу Івниці), А.І. Барбарич (1955) - у заказнику «Кам'яна гірка» в Овруцькому р-ні (Орлов, 2005; Мельник, 2008). На сьогодні наявність виду в описаних раніше локалітетах не підтверджена. (C) I.B. ХOM'ЯK, 2014
К. Гольде в 1872 р., знайшовши B. lunaria в межах сучасного м. Житомира (Соколова гора), описує цю місцевість як «зарості». Біотоп, де зростає вид iз 1991 р. в районі м. Житомира, є типовим для виду - це галявина дубового лісу.

Новий локалітет B. lunaria виявлений в урочищі «Потеребчуковий рів», на північно-західній околиці с. Старі Велідники Овруцького р-ну, на протилежному боці балки від місцезнаходження іншого рідкісного виду - Cypripedium calceolus (Хом'як, Дідух, 2010). Botrychium lunaria зростає в середній частині досить крутого $\left(60-75^{\circ}\right)$ східного схилу балки на висоті 1-7 м від дна (глибина балки 10 м). Грунт середньозмитий сірий лісовий, на поверхню виходять легкосуглинкові леси. Ділянка повністю покрита деревною і чагарниковою рослинністю (березовими й осиковими лісами). Трав'яниста рослинність на момент опису (19.05.2013) розріджена. Територія довкола місцезнаходження виду забруднена побутовим сміттям. Плакор зайнятий приватними сільськогосподарськими угіддями.

Локалітет сформований нерівномірно розміщеними особинами виду, чисельність і концентрація яких збільшується від дна до верху схилу, але за 2 м до плакорної частини зникає. Ярус дерев розріджений (зімкнутість нижче 0,7). Дерева віком 30-40 років ростуть вище по схилу, але певну частину доби створюють затінення локалітету $B$. lunaria. В ньому переважають Populus tremula L. $(0,7)$, рідше - Pinus sylvestris L. $(0,1)$. Підріст із $P$. tremula та Betula pendula Roth розріджений $(0,1)$.

Чагарниковий ярус формують Lonicera xylosteum L. $(0,5-0,8)$ i Frangula alnus Mill. $(0,4-0,6)$. Трапляються також поодинокі особини Sorbus aucuparia L. $(0,1)$. Спостерігаються численні проростки та молоді рослини Rubus caesius L. $(0,3)$, Dryopteris filix-mas (L.) Schot $(0,2)$, Cystopteris fragilis (L.) Bernh $(0,1)$. 


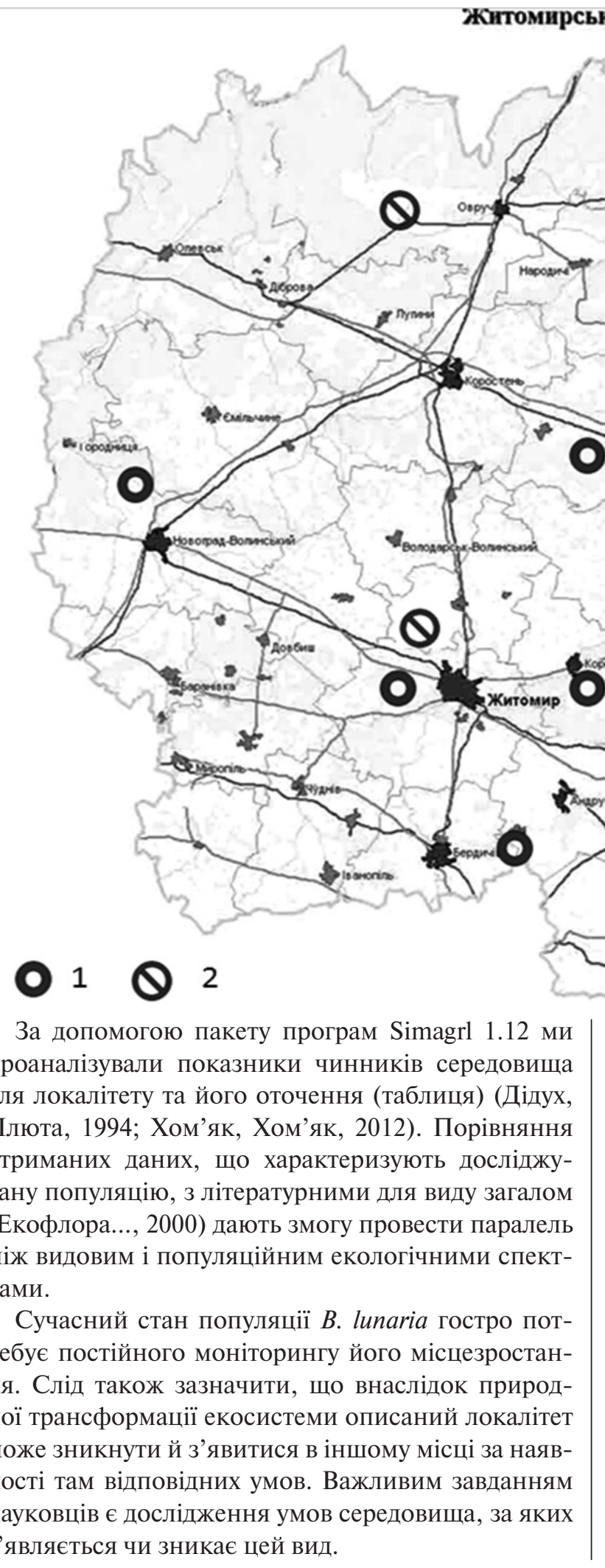

Карта-схема розміщення локалітетів Botrychium lunaria на території Житомирської обл. У п о 3 н а ч е н н я: 1 - локалітети, що, напевно, зникли; 2 - існуючі місцезнаходження виду

Map of localities of Botrychium lunaria in Zhytomyr Region. S y m b o ls in d i c a t e: 1 - localities that probably disappeared, 2 - existing locations 
Показники факторів середовища для досліджуваного місцезнаходження та порівняння їх з екологічним спектром виду

\begin{tabular}{|c|c|c|c|c|c|c|c|c|c|c|c|c|c|c|}
\hline \multirow{2}{*}{ * } & \multicolumn{14}{|c|}{ Показники факторів середовища (в балах)** } \\
\hline & Hd & Fh & Re & SI & $\mathrm{Ca}$ & $\mathrm{Nt}$ & Ae & $\mathbf{T m}$ & Om & Kn & $\mathrm{Cr}$ & Le & $\mathrm{He}$ & St \\
\hline 1 & 12,31 & 5,09 & 6,50 & 6,31 & 7,16 & 5,22 & 6,97 & 8,31 & 13,19 & 7,97 & 8,03 & 5,28 & 7,16 & 8,59 \\
\hline 2 & 11,68 & 5,84 & 7,60 & 6,92 & 6,71 & 6,03 & 6,37 & 9,00 & 12,98 & 7,85 & 8,48 & 5,50 & 7,47 & 7,29 \\
\hline 3 & 11,80 & 5,76 & 7,50 & 6,74 & 6,76 & 6,08 & 6,34 & 8,96 & 12,90 & 7,74 & 8,52 & 5,46 & 7,39 & 7,53 \\
\hline 6 & 0,01 & 0,01 & 0,20 & 0,48 & 0,15 & 0,44 & 0,01 & 0,17 & 0,16 & 0,05 & 0,02 & & 0,13 & 0,73 \\
\hline 7 & $8-16$ & $4-7$ & $3-9$ & $2-7$ & $3-9$ & $3-5$ & $5-8$ & $3-12$ & $11-20$ & $1-14$ & $5-12$ & & $4-9$ & $3-6$ \\
\hline 8 & 12 & 5,5 & 6 & 4,5 & 6 & 4 & 6,5 & 7,5 & 15,5 & 7,5 & 8,5 & & 6,5 & 4,5 \\
\hline
\end{tabular}

П р и м і т к и: * 1-3 - ділянки, в яких наявна Botrichium lunaria, 4 - ділянки оточення локалітету, 5 - середнє значення показників відповідного фактора даної популяції, 6 - відхилення популяційного оптимуму від видового, $7-$ амплітуда показників фактора для виду, 8 - оптимум значень показників фактора для виду. ** Фітоіндикаційні показники факторів у балах за уніфікованою шкалою Я.П. Дідуха та П.Г. Плюти, 1994: Hd - вологість грунту, Fh - змінність зволоження, Rc кислотність, $\mathrm{Sl}$ - сольовий режим, Са - вміст карбонатів, $\mathrm{Nt}$ - вміст доступного нітрогену, Ае - аерація, Тm - терморежим, Om - омборежим, Kn - континентальність, Cr - кріорежим, Lc - освітленість, Не - рівень антропогенної трансформації, $\mathrm{St}$ - ступінь природної трансформації.

Орлов О.О. Рідкісні та зникаючі види судинних рослин Житомирської області. - Житомир: Волинь, ПП «Рута», 2005. - 296 с

Смик Г.К. Рідкісні і реліктові рослини ОвруцькоСловечанського кряжа та їх охорона // Охорона природи та раціональне використання природних ресурсів. - К.: Наук. думка, 1970. - С. 50-52.

Хом'як І.В., Хом'як Д.І. Нова програма екосистемологічного моніторингу «SIMARGL» // Сучасні проблеми екології та геотехнологій. - Житомир, Вид-во ЖДТУ, 2012. C. 76 .

Хом'як І.В., Дідух Я.П. Нова знахідка Cурripedium calceolus L. на Житомирському Поліссі // Укр. ботан. журн. 2009. - 66, № 6. - С. 820-824.

Рекомендує до друку

Я.П. Дідух
И.В. Хомяк

Житомирский государственный университет имени И. Франко, Украина

НОВОЕ МЕСТОНАХОЖДЕНИЕ BOTRYCHIUM LUNARIA (OPHIOGLOSSACEAE) НА ТЕРРИТОРИИ ЦЕНТРАЛЬНОГО ПОЛЕСЬЯ

На территории Словечанско-Овручского кряжа выявлено новое местонахождение Botrychium lunaria (L.) Sw. Это его второе местообитание на территории Центрального Полесья. Популяция характеризуется высоким числом особей и различными условиями среды. Находка вида в пределах проектируемого международного биосферного резервата имеет важное значение и повышает природоохранный статус этой территории.

Ключ че в ы е слов в: Botrychium lunaria, СловечанскоОвручский кряж, Центральное Полесье, экологический спектр.

I.V. Khomyak

Zhytomyr Ivan Franko State University, Ukraine

A NEW LOCALITY OF BOTRYCHIUM LUNARIA (OPHIOGLOSSACEAE) IN CENTRAL POLESSYE

In the territory of the Slovechansko-Ovruchskyi Ridge, a new locality of Botrychium lunaria (L.) Sw. has been found. This is the second habitat of this species in Central Polessye. The population is characterized by a large number of individuals and environmental conditions. A find of this species within the planned Bilateral Biosphere Reserve is of great importance and raises the biodiversity conservation status of the territory.

K e y w o r d s: Botrychium lunaria, Slovechansko-Ovruchskyi Ridge, ecological spectrum. 